\title{
Decision Support System for Rural Water Supply in the Nilgiris District of South India
}

\author{
D. R. Olsen, S. E. Dickson and B. W. Baetz \\ Department of Civil Engineering, McMaster University, 1280 Main Street West, Hamilton, ON L8S 4L7, Canada
}

\begin{abstract}
A considerable amount of knowledge exists for planning, designing, and implementing rural water supply schemes in developing countries around the world. Generalized decision support systems (DSSs) are used to tackle the daunting task of providing water in areas that have poor water resources and limited financial capacity. However, there is a lack of site-specific DSSs that utilise local hydrological and socio-economic data for assessing regionally-based rural water supply schemes. In the Nilgiris District of South India, an organizational structure exists for improving local water resources through watershed management projects, but many of the tools used to make informed decisions are ineffective, leading to poorly designed systems. Addressing this problem, a prototype DSS called Nilgiris Rural Water Supply (NRWS) was developed for rural water supply in the Nilgiris District. It assists planners in developing a decision-matrix for potential water sources based on six criteria: water source yield; capital costs; cost and ease of operation and maintenance; impact of development; political/legal constraints; and water quality. Within the water source yield criterion, a simulation method was used to develop design specifications for the rainwater harvesting (RWH) source. A general application of the rooftop RWH simulation was applied to ten villages throughout the Nilgiris District. One important discovery was that the village of Masinigudi, which lies in a rain shadow and receives the lowest level of annual rainfall in the district, performed to the same level as villages with a high annual rainfall. Since the region surrounding Masinigudi is deprived of water sources, such as mountain streams and dug wells, RWH was found to be a feasible and economically viable solution.
\end{abstract}

Keywords: Decision support system, India, non-government organization, rainwater harvesting, rural water supply, water resource management

\section{Introduction}

The Millennium Development Goals were created by the United Nations in the year 2000 to generate an international effort to fight poverty and disease. One of the goals related to water is to reduce by half, by 2015 , the proportion of people without sustainable access to safe drinking water. Currently there are over one billion people worldwide without access to potable water; the majority of whom live in Africa and Asia (De Villiers, 1999). While the deficiency of economic wealth contributes to the lack of potable water supplies, poor water resource management is also a major cause. In India, the groundwater supply is gradually depleting, limiting the ability of rivers and lakes to maintain water during the dry season (Lal, 2002). During heavy monsoon periods, rainwater erodes the topsoil and transfers non-potable water to the oceans as runoff rather than recharging the groundwater supply.

General computer software programs incorporating various methodologies are commonly used to assist decision makers in selecting and designing rural water supply systems in developing countries. However, many of these applications are ineffective since they require data that are difficult and time consuming to obtain, and do not incorporate social and

\footnotetext{
* Corresponding author: baetz@mcmaster.ca
}

cultural aspects of local conditions. Computer programs are more likely to be successful if they minimize the need for gathering complex data, use models that are applicable to local conditions, and incorporate non-technical factors into the program algorithms. The overall purpose of this paper was to report on the development of a DSS called NRWS for the selection of rural water sources in the Nilgiris District of Southern India. A partnership was formed with the Rural Development Organisation (RDO) to integrate the DSS into the decision-making structure for rural water supply in the district.

\subsection{Rural Water Supply in the Nilgiris District}

Ingenuity in dealing with water resources has thrived for thousands of years in India. Traditional methods of simple stone-rubble structures for impounding rainwater were used 5000 years ago in the Baluchistan District (Gould and Nissen-Peterson, 1999). Recently, many rural establishments in India have resorted back to the traditional methods of collecting runoff and rainwater due to the inability of aquifers to meet current demands. In the state of Tamil Nadu, the registration of boreholes has become required by law, and substantial fines are imposed for unauthorised drilling of wells (Radharkrishna, 2003). Although this regulation seems drastic, it is essential for ensuring the sustainability of ground- 
water as a resource. Thus, in the Nilgiris District, an emphasis is placed on recharging aquifers through water harvesting techniques, as opposed to reckless mining of groundwater through deep boreholes. Creating temporary storage reservoirs on small mountain streams is a popular technique in the Nilgiris District. These check dams are ideal for use in a monsoon climate where there is a need to store surplus water from the rainy season for use during the dry season (Hanson and Nilsson, 1986). Additionally, rooftop RWH has recently become mandatory by the law in the state of Tamil Nadu (Radharkrishna, 2003). Although such a law is not strictly enforced, the use of rainwater as a potable water source is gaining popularity in regions where a clean surface water source is not available.

\subsection{Existing Framework for Decision-Making in the Nilgiris District}

All development initiatives within the Nilgiris District are carried out under the guidance of the government "Hill Area Development Program" (HADP). In 1995, the HADP delineated the Nilgiris District into 75 macro-watershed areas for the purpose of spatially merging activities into watershed management projects. These projects were intended to improve the social conditions of the villagers while improving the environmental stability of the area through improved forest and agricultural land management. The projects brought together all government departments and non-government organizations into a cohesive unit to implement works and activities that have the most social and environmental benefit. One component of the projects was to assess the existing rural water supply structures for each watershed village. The role of the non-government organization (NGO) was to communicate with villagers and to form self-directing village associations. One NGO was assigned to each watershed to coordinate the efforts and act as a link between the government departments and village water associations.

\subsection{Community Involvement in DSS Development}

For a rural water supply project to be effective, a focus must be placed on empowering the local community to actively participate at every level of the decision-making process. With a sense of control and autonomy, the community is likely to take pride in the project, improving the organizational structure necessary to operate and maintain the system (Pasteur, 2002). Three case studies for water projects in Sri Lanka and India showed a positive correlation between successful projects and high community-level involvement (Isham and Kahkonan, 2002). Since the value systems and perceptions of the villagers are reflected within the structure of NRWS, the NGO field staff working alongside the village associations were ideal users of the DSS.

Gathering data that accurately represents the villagers' perceptions and village conditions is challenging. The HADP projects accomplish this task through participatory rural assessment (PRA) exercises conducted by the NGOs. The purpose of the PRA is to assess the villagers' perceptions about their problems and needs, as well as to determine the opportunities that exist for improvement. Through the PRA, information is obtained on the history of existing water supply systems and the water demand of the village. Exercises include developing time lines to understand the village's history, seasonality diagrams to understand the conditional changes throughout the year, and social mapping to illustrate how people identify their own village (Deverill et al., 2002).

The development of NRWS is described in the next section, including a breakdown of the criteria used to evaluate potential water supply sources. Following this section, the RWH model component of NRWS was applied to ten villages throughout the District to determine the effectiveness of using the RWH source throughout the district.

\section{DSS Development}

NRWS incorporated a broad spectrum of features into the DSS algorithms in order to include all the factors influencing rural water supply selection in the Nilgiris District of South India. Since the technical capacity of the projected users is limited, NRWS focused on maintaining a user-friendly interface by concealing the algorithm complexities. However, the inherent social complexities surrounding water supply issues within a village requires the NRWS user to have both a good rapport with the village and effective mechanisms for village capacity building.

The shell of NRWS was developed through Microsoft ${ }^{\circledR}$ Excel using the Visual Basic for Applications programming language. A user-friendly interface was established through a network of links and forms that directs the user through the program functions. NRWS was divided into six modules that represented six different criteria used to evaluate potential water sources: acceptable yield; capital costs; cost and ease of operation and maintenance; impact of development; political and legal constraints; and water quality (Figure 1).

Sub-modules within the first three criteria allow the user to calculate yield and cost for each potential water source being evaluated. There are many different sources that were used to supply water for domestic use; however, only five were considered in NRWS due to their popularity within the Nilgiris District. These water sources included rooftop rainwater harvesting, check dams, reservoirs, springs, and dug wells.

Help files for every module and sub-module were made available to the user through a customized help menu. For simplification purposes, the main menu of NRWS was structured as a hub for transferring between the six modules and the DSS results worksheet. A user-form was created on the main menu to update the list of potential water sources if additional ones became available after the initial file was started.

One underlying objective of NRWS was not to carve a specific path for the user to follow, but to give the user flexibility in assessing the needs of a specific village. This 


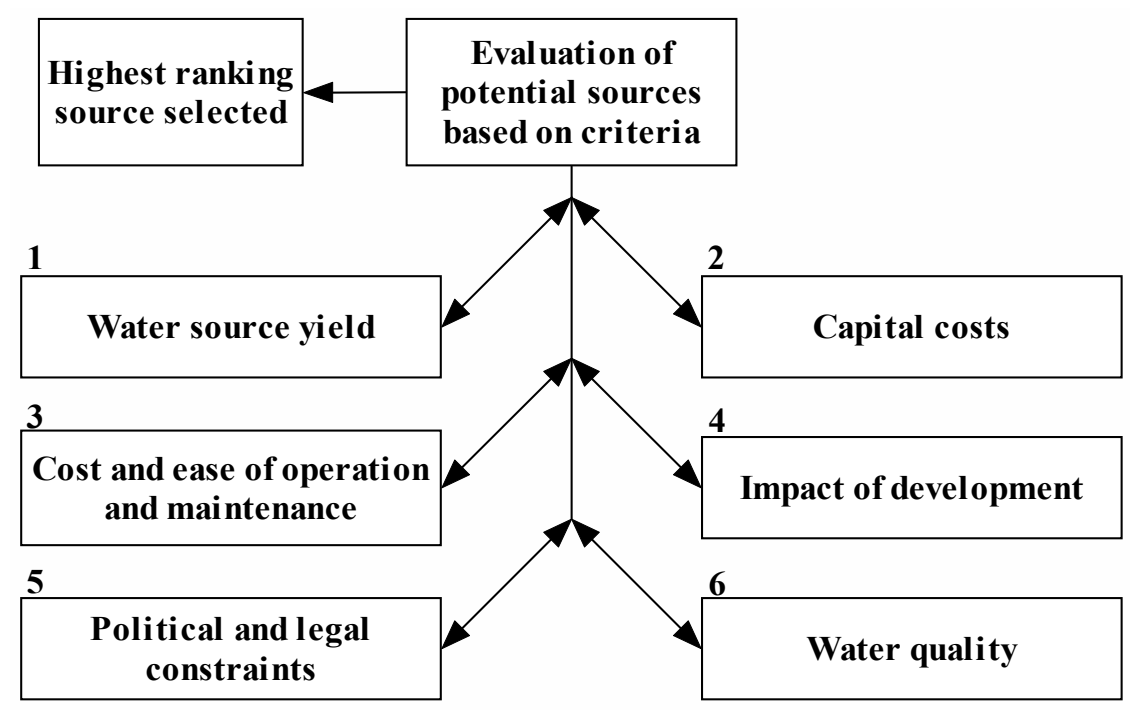

Figure 1. Criteria used in the process of selecting appropriate rural water sources.

was important since villages do not necessarily share the same set of ideals and conditions. As such, NRWS gathers and organizes the information necessary for quantifying water source attributes, and allows flexibility in how those attributes are perceived by the local village. The technique used for this purpose was a decision-matrix tool which involves the user assigning a weight to each criterion, and a score to each potential source within that criterion (House and Reed, 1997). This system is a widely accepted tool for decision-making and allows the user to apply greater influence to the criteria that are more important to the village. When the six weighted scores are summed for each potential water source, the total scores are compared and ranked in order to determine ideal sources to implement. The results of the decision support system are displayed in a table which lists the weighted scores and ranking of each source, and in a bar graph that illustrates the significance of each criterion for each source (Figure 2).

\subsection{Module 1: Water Source Yield}

Obtaining an adequate supply of good quality water is crucial to the health and well-being of the local population. If only one water source is being used to supply a village, water source yield is the most important criteria (Gould and Nissen-Peterson, 1999). A number of regions in India experience an extended dry season that lasts three to five months. It is during this period that rural water supply systems fall short of meeting the demands of the village. Therefore, accurate yield estimates for potential water sources minimize the risk of water deficiencies after implementation.

Determining the water demand of a village includes a process that incorporates the opinions and ideas from every member of the village. Effective communication between stakeholders is vital if demand is to be met (Deverill et al., 2002). Evidence indicates that the misjudgement of water demand is an important factor contributing to the failure of water projects in developing countries (Parry-Jones, 1999). The approach used in the Nilgiris District to assess village water needs is a Participatory Rural Assessment. Within the NRWS, the user inputs the total number of villagers and daily water demand for every month of the year to account for seasonal variations in demand. If the village being assessed has existing water supplies that continue after the new water source is implemented, a link is activated by the user to input the existing water supply.

Once the village water demand is established, unique methods are used to estimate the water yield of every potential water source. Yield is represented as a percent reliability which indicates to the user how often the system fails based on historical data. Since the limiting factor for using large hydroelectric reservoirs is not water yield but water quality, a simple method was used which compares a six-month village water demand to the reservoir volume during the dry season (USAID, 1982). For the dug well water source, below grade characteristics are difficult and expensive to determine. As such, the method chosen for NRWS utilized maximum pumping rates based on field data (House and Reed, 1997). The remaining three potential water sources (spring, check dam, and rainwater harvesting) all used a simulation approach.

In order to develop an approach for the RWH source, a number of different methods were compared. Rees (1999) and Gould and Nissen-Peterson (1999) described a variey of techniques including demand-side approach, mass balance analysis, statistical methods, and computer simulations. The basis of the demand-side approach is to provide enough storage to meet user demand during the dry season. This is a simple approach that is suitable for regions that have a distinct dry season, but it does not take into account yearly variations in precipitation. Mass balance analysis calculates the required 


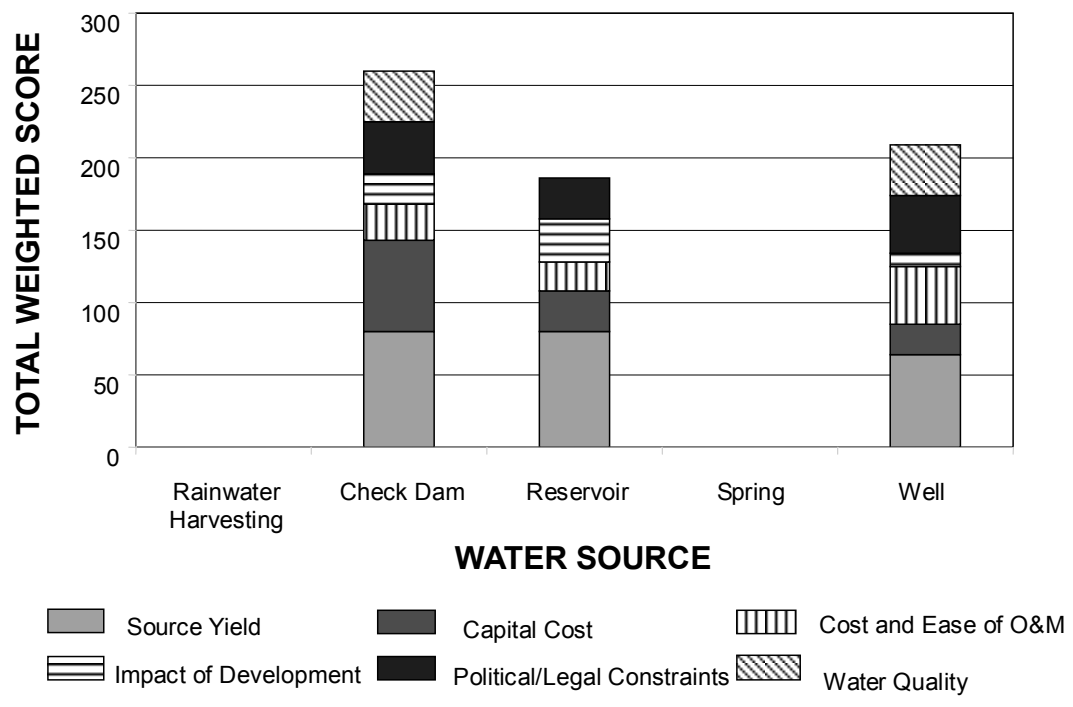

Figure 2. Results of the DSS in graphical format.

storage by taking the maximum difference between cumulative monthly rainfall inflows and cumulative demand. By applying standard statistical techniques, the mass balance approach can be enhanced by developing minimum rainfall based on a given confidence interval or probability. This statistical approach does not use daily data which provides a more accurate predication of system performance (Heggen 1996, Gould and Nissen-Peterson, 1999). If the computers are available, they allow for a high degree of flexibility. The Ajit foundation in India developed a simulation program called SimTanka, which simulates the fluctuating rainfall for which the RWH system is dependent (Vyas, 1999).

Since daily rainfall data and computing hardware were available in the district, the simulation method was chosen for the RWH source. Ten years of daily precipitation data from nineteen rain-gauge stations were gathered for use in the simulation. The total area of the Nilgiris District is $2452 \mathrm{~km}^{2}$, giving the 19 rain gauge stations an average density of one gauge per $136 \mathrm{~km}^{2}$. This was within the established guidelines set by the World Meteorological Organization for the minimum density of precipitation networks for tropical mountainous regions of 100 to $250 \mathrm{~km}^{2}$ (Wilk, 2000). Therefore, it was assumed that the precipitation database adequately represented the Nilgiris District.

The technique used to estimate point precipitation data was a weighting method developed by the Hydrologic Research Laboratory in the United States (Viessman, 1995). For 95 village locations across the district, rainfall was estimated by establishing a set of axes running through each point, and taking the weighted average of precipitation at surrounding locations based on distance. Other data that were required to run the simulation included the percent reliability required by the villagers and village rooftop characteristics (Figure 3).

To better understand the RWH simulation model, the storage unit acts as the central processing module with numerous inflows and outflows. For each simulation day, if rainfall occurs, the respective volume captured by the rooftop is transferred to the storage unit. The volume of water consumed by the village is extracted from the storage unit on a daily basis. If the storage unit reaches its capacity after the inflow from rainfall and outflow from consumption, the excess volume of water spills over and is considered an outflow. The simulation runs 3650 times, representing ten years of daily data. A failure in the system occurs when the demand cannot be met due to a lack of water in the storage unit. The number of failures are accumulated and used to calculate the percent reliability of the system. Equations 1 to 3 are used to run the simulation and were developed by Heggen (1996).

$C_{i}=\min \left\{\begin{array}{c}S_{i-1}+A P_{i} z \\ D_{i}\end{array}\right.$

$Q_{i}=\max \left\{\begin{array}{c}S_{i-1}+A P_{i} z-V-C_{i} \\ 0\end{array}\right.$

$S_{i}=S_{i-1}+A P_{i} z-Q_{i}-C_{i}$

where $A$ is catchment area $\left(\mathrm{m}^{2}\right) ; S_{i}$ is storage at the end of period $i(\mathrm{~L}) ; C_{i}$ is consumption in period $i(\mathrm{~L}) ; Q_{i}$ is spill in period $i(\mathrm{~L}) ; D_{i}$ is target water demand for period $i$ (L/day); $V$ is storage capacity $(\mathrm{L}) ; P_{i}$ is rainfall over given time pe$\operatorname{riod}(\mathrm{mm}) ; z$ is runoff coefficient.

\subsection{Module 2: Capital Costs}

When funds are readily available for a water supply system, an emphasis is typically placed on matching the water 


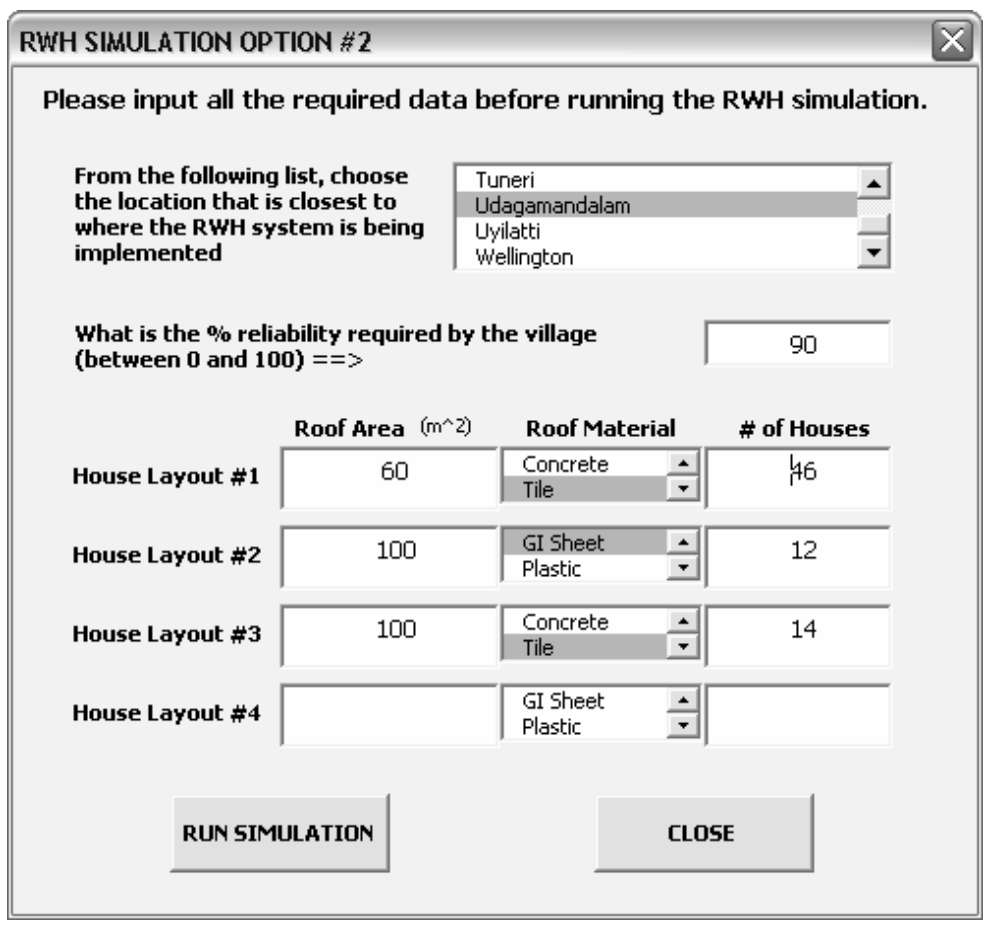

Figure 3. User form for rainwater harvesting simulation.

source yield to user demand, regardless of cost. In economically poorer countries like India, a greater emphasis is placed on finding financially viable water sources (Pacey and Cullis, 1986). Module 2 of NRWS estimates the capital cost of potential water sources. The central Module 2 worksheet is set up in table format to provide the user with the tools needed to accurately assess the criterion. The first table outlines the total capital cost for each water source and enables the user to enter a score, while the second table is a set of guidelines to help the user assign reasonable scores to each source. Ranging from one to ten, the score descriptions in the second table assess whether the source is economically feasible, with a lower score indicating an increased reliance on external assistance. The lowest possible score specifies a water source that is not economically feasible after assistance from all possible funding agencies.

From the central Module 2 worksheet, the user has the option of following five links to input the capital cost components for each potential water source. Instructions are provided to the user on inputting the number of units for each cost component in the lighter cells of the worksheet table. The darker cells describe the construction materials/activities required to implement each water source, and their respective unit cost (Table 1). The total cost is calculated and transferred to the central Module 2 worksheet.

Material costs for all government works are developed on a yearly basis for each district in the State of Tamil Nadu and

Table 1. Example Costing Table for Module 2

\begin{tabular}{|c|c|c|c|c|c|}
\hline SI \# & $\begin{array}{l}\text { DESCRIPTION OF WORK/MATERIAL } \\
\text { PIPELINE AND PUMP }\end{array}$ & Unit & $\begin{array}{l}\text { Unit Cost } \\
\text { (Rs.) }\end{array}$ & $\begin{array}{l}\text { Number of } \\
\text { Units }\end{array}$ & $\begin{array}{c}\text { Amount } \\
\text { (Lakh) }\end{array}$ \\
\hline $\mathrm{a}$ & Drinking Water Pipeline, B-Class (2") & $20 \mathrm{ft}$ & 975 & - & - \\
\hline $\mathrm{b}$ & Drinking Water Pipeline, B-Class (1.5") & $20 \mathrm{ft}$ & 675 & - & - \\
\hline $\mathrm{c}$ & Drinking Water Pipeline, B-Class (1") & $20 \mathrm{ft}$ & 520 & - & - \\
\hline $\mathrm{d}$ & Drinking Water Pipeline, B-Class (3/4") & $20 \mathrm{ft}$ & 330 & - & - \\
\hline $\mathrm{e}$ & 10 Hp Electric Motor & No. & 40,000 & - & - \\
\hline $\mathrm{f}$ & Motor Shed & No. & 50,000 & - & - \\
\hline
\end{tabular}




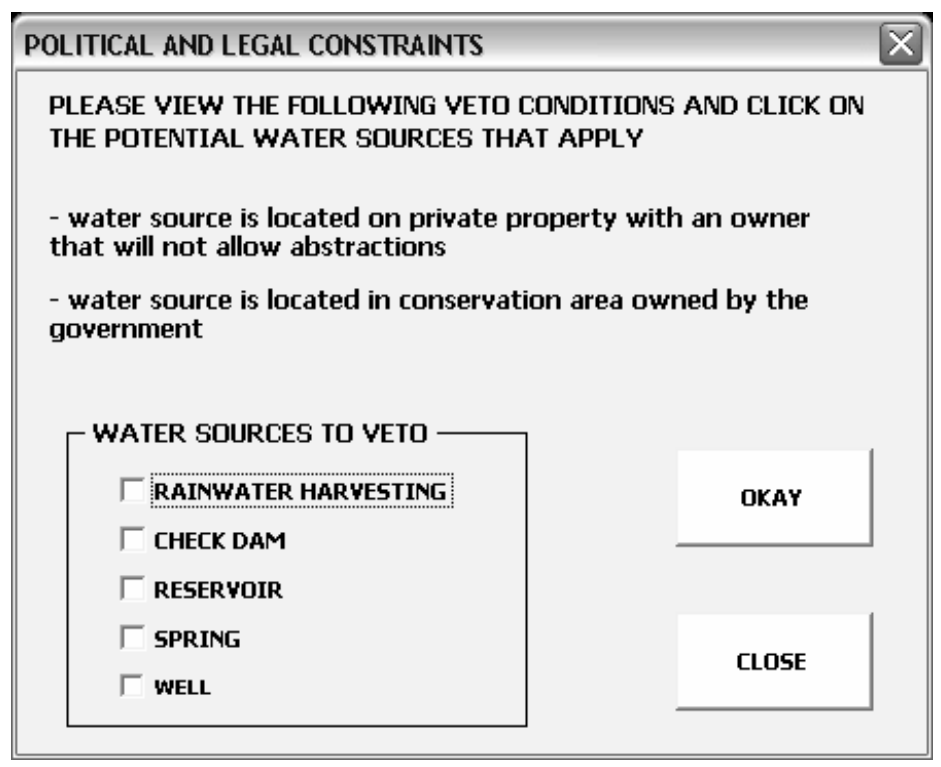

Figure 4. Form that allows user to veto sources that are not legally feasible.

presented in a document called the Standardised Schedule of Rates. All costing rates used in NRWS were taken from an Agricultural Engineering Department (2004) report and Sahu (2002) which used the 2003 and 2002 Nilgiris District Standardised Schedule of Rates respectively.

\subsection{Module 3: Cost and Ease of Operation and Maintenance}

Creating mechanisms to effectively operate and maintain a water source ensures system longevity and high performance. Research has shown that: (1) inaccurate development of operation and maintenance costs often leads to insufficient funds to sustain a project; (2) replacement costs are rarely taken into consideration, resulting in many problems when the infrastructure requires renewal; and (3) subsidies are inadequately targeted and rarely benefit the vulnerable members of society (Deverill et al., 2002). Module 3 of NRWS organizes information pertinent to deciding whether a village is capable of operating and maintaining potential water sources based on the economic and labour contributions from villagers.

Based on a standardized cost component sheet for all water sources, the user inputs the number of units for each material/work that is required to sustain each source over a twenty-year lifespan. Since the operation and maintenance costs are subject to unknown conditions over time, an estimate of each cost component is developed through historical data based on past rural water supply systems, and quantitative assessments where possible. Additionally, the time value of money is an important factor since the operation and maintenance costs are incurred over an estimated twenty-year infrastructure lifespan. Depending on the inflation and interest rates of the local and international economy, the value of one
Rupee today purchases more materials than one Rupee in ten years time (Deverill et al., 2002). Therefore, NRWS prompts the user for the current interest rate and uses equations described by Ross et al. (2002) to calculate the present value of costs incurred at a later date input (Equations 4 and 5):

$$
\begin{aligned}
& A F(r, n)=\frac{\left[1-(1+r)^{-n}\right]}{r} \\
& \text { Annuity }=\frac{\text { CurrentValue }}{A F(r, n)}
\end{aligned}
$$

where $A F$ is Annuity Factor; $r$ is interest rate; $n$ is number of years.

After inputting all required variables, the willingness of the village to pay for improved services is presented as a percentage of the total costs. This enables the user to effectively assign a score for each water source. To further assist the user, a qualitative set of guidelines describes three factors that encompass the ease of operation and maintenance. First, high level technologies necessitate the need for specialized personnel to maintain the system. As a result, the local management team must have the capacity to deal with such circumstances or the system will inevitably break down. Second, if the water supply system relies on electricity to provide water to the local population, the unpredictability of the power grid in the district creates uncertainty in the performance level. Third, the ease of operating and maintaining a water source depends on its distance to the village. Many villages in the Nilgiris District do not have nearby water sources. Instead, they rely on pipelines to transfer water from 
Table 2. Variables Transferred from Module 1 to Module 4

\begin{tabular}{|c|c|c|}
\hline Source & Transferred variable & Impact description \\
\hline RWH & $\begin{array}{l}\text { Average household storage } \\
\text { requirement }\end{array}$ & $\begin{array}{l}\text { - large storage units beside households may not be aesthetically } \\
\text { pleasing to the villagers } \\
\text { - required storage size may not spatially fit the dimensions of the } \\
\text { village }\end{array}$ \\
\hline Check dam & Reservoir storage requirement & $\begin{array}{l}\text { - land encroached by the reservoir may negatively affect local flora } \\
\text { and fauna } \\
\text { - downstream villages may also rely on stream water }\end{array}$ \\
\hline Reservoir & $\begin{array}{l}\% \text { of reservoir used by village over } \\
\text { six months }\end{array}$ & $\begin{array}{l}\text { - consumption of water during the dry season may significantly } \\
\text { reduce reservoir levels }\end{array}$ \\
\hline Spring & Spring pond storage requirement & $\begin{array}{l}\text { - land encroached by the reservoir may negatively affect local flora } \\
\text { and fauna }\end{array}$ \\
\hline Dug well & Depth of water table & $\begin{array}{l}\text { - low water table levels may indicate unsustainable groundwater } \\
\text { yield conditions }\end{array}$ \\
\hline
\end{tabular}

far off sources such as check dams. Water sources not located in the general vicinity of the village are less likely to be maintained on a regular basis, increasing the chance of premature technical malfunctions.

\subsection{Modules 4/5: Impact of Development and Political/Legal Constraints}

The qualitative nature of Modules 4 and 5 minimizes the need to develop complex algorithms for comparing potential sources. User input is influenced by assessing a list of potential variables that inhibit the ability of the water source to perform at an acceptable level. Potential environmental im- pacts include any actions that jeopardize the sustainability of the water cycle, and alterations to the physical geography that negatively affect the local flora and fauna. For example, the construction of a check dam on a mountain stream engulfs a large area of land if the terrain is wide and broad but not if the land is narrow and steep. Additionally, drilling deep into aquifers and withdrawing water at a rate that cannot be sustained lowers the water level significantly. These impacts and their consequences must be well understood prior to developing a source. At the same time, developing certain sources may go against the cultural or religious norms of the local population, or may not be aesthetically pleasing. In order to assist the user

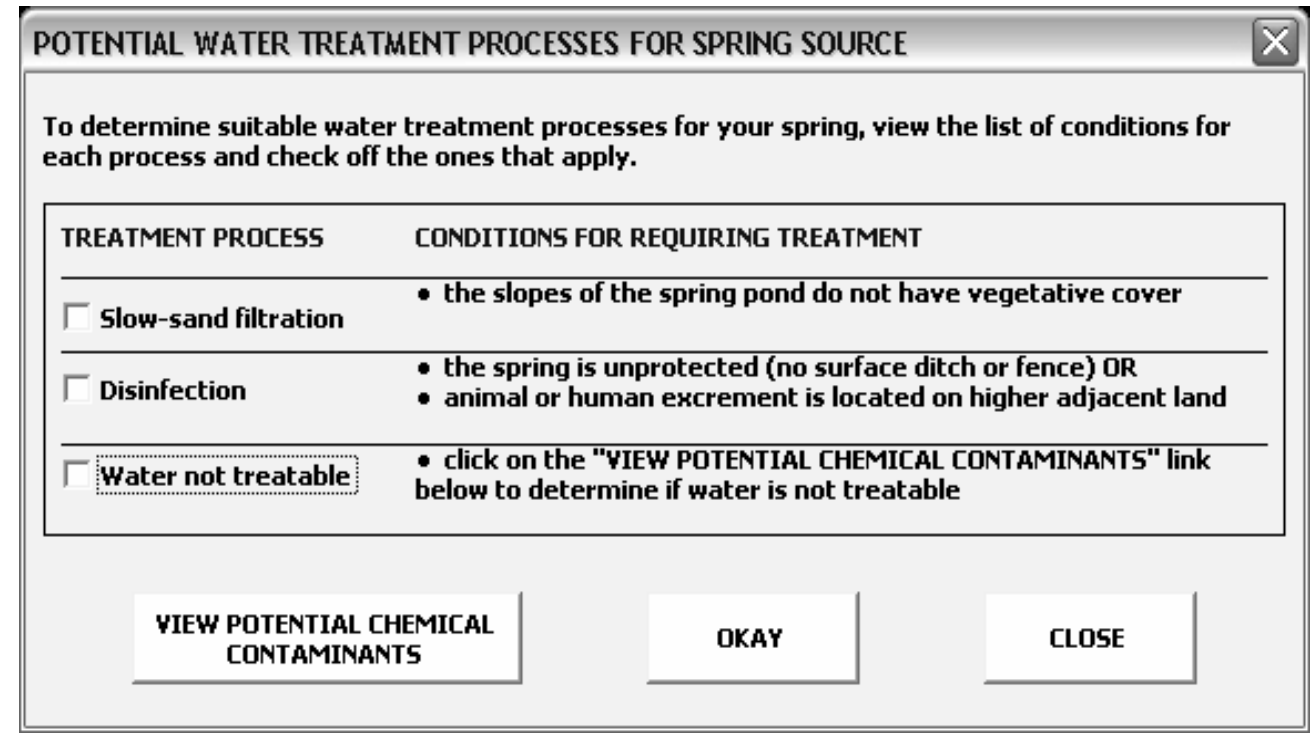

Figure 5. User form to assess required treatment processes for spring source. 
identifying potential environmental and human impacts of development, a number of variables are transferred from the sub-modules of Module 1 to the Module 4 worksheet as described in Table 2.

In addition to the normal procedure of assigning scores and weights to each criterion, Module 5 has the ability to veto a potential water source if it does not fall into the legal or political framework of the local government (House and Reed, 1997). Such circumstances arise when the source is located on the private property with an uncompromising owner or on government conservation land where development is prohibited. A veto clause is necessary only for Module 5 since the other criteria deal with economic conditions which can be overcome, soft issues which can be adapted to, or water quantity/quality conditions that can be either improved upon or accepted. Potential water sources can be vetoed through a user form initiated from the Module 5 worksheet which provides a list of the sources along with various circumstances for rejection (Figure 4).

\subsection{Module 6: Water Quality}

In emergency situations, accessing a reasonable quantity of water is more important than ensuring the water is free of contamination. However, when developing a long-term solution to rural water supply, the quality of water directly impacts the health of the villagers, becoming an important factor. Microbiological contamination from human and animal waste pose the greatest risk to human health (WHO, 1993). Currently in the Nilgiris District, most villages employ inadequate disinfection systems with inefficient and random doses of chlorine, and rarely use other treatment processes. Only in reservoirs with high turbidity and/or chemical contamination are treatment practices like filtration and sedimentation implemented, which still do not provide adequate treatment of chemical contaminants. The problem of treating water in the Nilgiris District exists for two reasons: the government does not have the technical or economic capacity to treat all sources of water; and there is no organizational structure for assessing the need for treatment. Therefore, water sources should not be developed if known conditions exist that make it difficult to obtain an adequate level of quality. The purpose of Module 6 was to establish the processes required to adequately treat every potential water source for a village, and to determine whether these processes were economically and technically feasible.

Since equipment is not readily available to test water parameters, a simplified qualitative approach was used on the Module 6 worksheet to assess the need for water treatment processes. This approach was structured in a series of forms accessible from the Module 6 worksheet through a network of links representing each source. Each form lists the potential treatment processes for the respective source, and describes a number of conditions that must be satisfied for requiring treatment (Figure 5).

\section{Application of the Developed Decision Support System}

A wide range of criteria and water sources are used within NRWS for assessing rural water supply; however, only the water yield criterion for the RWH source is applied in this article due to space constraints. For further application details,

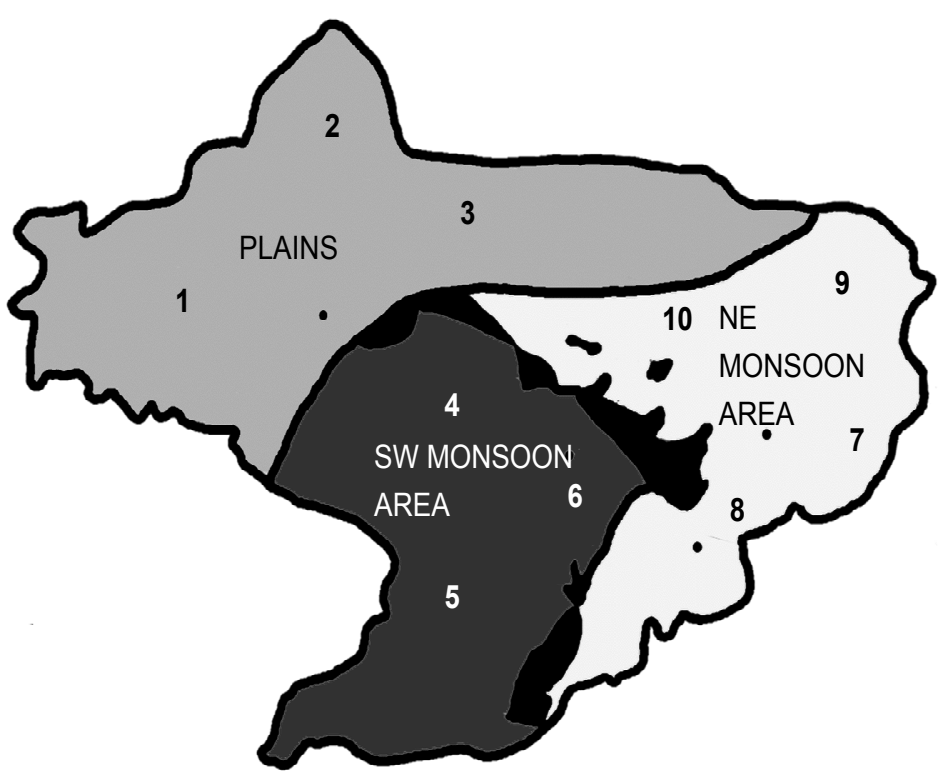

Figure 6. Precipitation regions within the Nilgiris District and RWH simulation village locations. 
refer to Olsen (2005), which is accessible through the web-link provided at the end of this article.

The rooftop RWH simulation model, which exists in the framework of NRWS, can also be used as a stand-alone software program. Since the simulation model contains an extensive database of daily precipitation data and requires easily accessible input data from the user, it is an effective design tool. The climate and physical geography varies greatly across the Nilgiris District, providing a range of rainfall conditions. As such, ten locations were tested to determine the effectiveness of using the source throughout the district.

\subsection{Selection of Villages for Simulation}

There are three distinct regions that influence precipitation patterns in the Nilgiris District based on topography and monsoon patterns. Therefore, the ten test villages were selected based on these three regions, and were spread evenly throughout the Nilgiris District. Table 3 lists the villages along with their respective region, and Figure 6 shows the village locations within the Nilgiris District.

Table 3. Villages Used for RWH Simulation

\begin{tabular}{ccc}
\hline Test site \# & Village & Region \\
\hline 1 & Pandalur & Plains \\
2 & Mudumalai & Plains \\
3 & Masinigudi & Plains \\
4 & Pykara & SW monsoon area \\
5 & Emerald valley & SW monsoon area \\
6 & Udagamandalam & SW monsoon area \\
7 & Nandipuram & NE monsoon area \\
8 & Denad & NE monsoon area \\
9 & Kodanad & NE monsoon area \\
10 & Uyilatti & NE monsoon area \\
\hline
\end{tabular}

The Plains region in the north sits at approximately 900 metres above sea level and is primarily influenced by the southwest monsoon period. Villages in the western part of the the Plains region receive a significantly larger amount of precipitation than those in the eastern section of this region due to the presence of a rain shadow. The western part of the Plains region is situated in the windward direction of the southwest monsoon, and therefore receives a high level of rainfall during this time period. On the other hand, the eastern section of the Plains region sits in the leeward direction of both the southwest and northeast monsoons creating a rain shadow that receives much less precipitation on an annual basis. The Nilgiris plateau which steeply rises from the plains to an elevation of 2600 metres above sea level constitutes the second and third regions that influence precipitation conditions in the district. The eastern section of the mountainous region is more strongly influenced by the northeast monsoon, whereas the western section receives a greater portion of water from the southwest monsoon.

\subsection{Description of Standard House Type}

The house type used to run the RWH simulation for each of the ten villages is based on a common construction practice found in Nilgiris District and within Southern India. Starting from the foundation, reinforced concrete columns are constructed below grade to the rooftop level. Walls are then erected and a concrete slab is casted on the floor. The rooftop material consists of Mangalore tiles which are distinctly unique to the region due to their bright orange colour. Since the percentage of water transferred to the storage tank directly relates to the rooftop material, it is an important characteristic. The house dimensions are six metres by ten metres, which is typically divided into three rooms separated by curtains that consist of a sleeping area, kitchen and common room. On average, four people live in this type of dwelling and each person consumes about 20 litres of water per day. Figure 7 illustrates the house type used for the simulation which has a working gutter system used to divert water away from the house as opposed to harvesting rainwater.

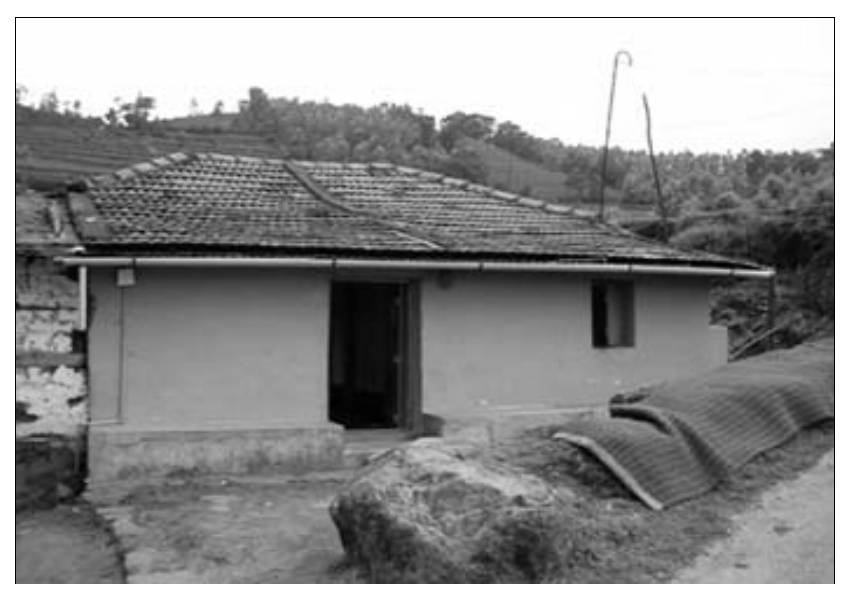

Figure 7. Typical dwelling unit in the Nilgiris district.

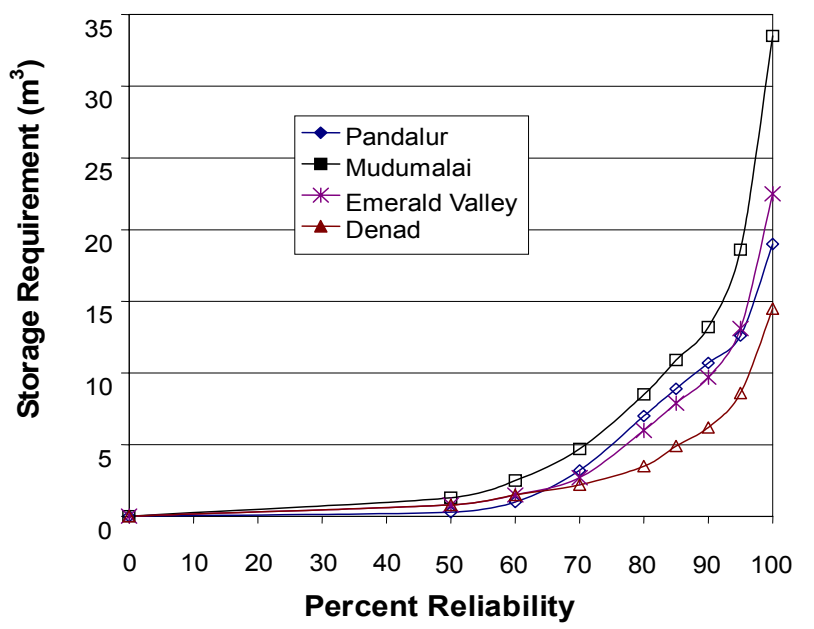

Figure 8. Graphical illustration of $\%$ reliability vs. storage for four villages. 
Table 4. Storage Requirements $\left(\right.$ in $\mathrm{m}^{3}$ ) for RWH Systems at Different \% Reliability Levels

\begin{tabular}{cccccccccc}
\hline Test site \# & Village & \multicolumn{9}{c}{ Overall perfect reliability } \\
\cline { 3 - 8 } & & 50 & 60 & 70 & 80 & 85 & 90 & 95 \\
\hline 1 & Pandalur & 0.3 & 1.0 & 3.2 & 7.0 & 8.9 & 10.7 & 12.6 & 100 \\
2 & Mudumalai & 1.3 & 2.5 & 4.7 & 8.5 & 10.9 & 13.2 & 18.6 & 33.5 \\
3 & Masinigudi & 0.8 & 1.5 & 2.2 & 4.5 & 6.4 & 7.7 & 9.6 & 17.5 \\
4 & Pykara & 0.8 & 1.5 & 3.2 & 6.5 & 8.4 & 10.2 & 12.1 & 17 \\
5 & Emerald valley & 0.8 & 1.5 & 2.7 & 6.0 & 7.9 & 9.7 & 13.1 & 22.5 \\
6 & Udagamandalam & 0.8 & 1.5 & 3.2 & 6.5 & 8.9 & 11.2 & 15.6 & 33 \\
7 & Nandipuram & 0.8 & 1.0 & 2.2 & 4.0 & 4.9 & 6.2 & 8.6 & 15 \\
8 & Denad & 0.8 & 1.5 & 2.2 & 3.5 & 4.9 & 6.2 & 8.6 & 14.5 \\
9 & Kodanad & 0.8 & 1.5 & 3.2 & 6.5 & 8.4 & 10.2 & 13.1 & 19 \\
10 & Uyilatti & 0.8 & 1.0 & 1.7 & 4.0 & 5.9 & 7.2 & 9.1 & 15 \\
\hline
\end{tabular}

\subsection{Analysis of Results}

The first part of the analysis developed the RWH storage requirements based on known percent reliability levels. Table 4 summarizes the results for each of the villages starting at a fifty percent reliability level. The percent increments decrease from ten to five starting at eighty percent in order to accurately depict the changes in storage requirements which change more rapidly at higher percent reliability levels.

Table 5. Percentage of Rainfall During the Three Seasons of the Year

\begin{tabular}{ccccc}
\hline $\begin{array}{c}\text { Test } \\
\text { site \# }\end{array}$ & Village & $\begin{array}{c}\text { SW monsoon } \\
\text { season }\end{array}$ & $\begin{array}{c}\text { NE monsoon } \\
\text { season }\end{array}$ & $\begin{array}{c}\text { Dry } \\
\text { season }\end{array}$ \\
\hline 1 & Pandalur & 70 & 20 & 10 \\
2 & Mudumalai & 63 & 19 & 18 \\
3 & Masinigudi & 47 & 33 & 20 \\
8 & Denad & 26 & 49 & 25 \\
\hline
\end{tabular}

Comparing the villages throughout the district, a general pattern emerged where the villages in the northeast monsoon-influenced region (villages 7, 8,9 and 10) performed better than the other two regions since they required less storage capacity in order to obtain the same percent reliability level. RWH units are typically designed for a $90 \%$ reliability level. The storage capacities required to meet this reliability are shown in bold for each test site in Table 4. Using this design constraint, the villages with the lowest storage requirement were Denad and Nandipuram at $6.2 \mathrm{~m}^{3}$, whereas Mudumalai required storage of $13.2 \mathrm{~m}^{3}$. There were a number of reasons for differing performance levels throughout the district. First of all, it is reasonably obvious that a village which receives more precipitation will require less storage to obtain the same yield. This was true when comparing the villages of Denad and Mudumalai which received an average annual rainfall of approximately $1500 \mathrm{~mm}$ and $1000 \mathrm{~mm}$ respectively; however, this hypothesis did not hold true in all simulation runs. The village of Pandalur received an average annual rain- fall of $2200 \mathrm{~mm}$ but required more storage capacity than Denad. This was caused by the difference in distribution of rainfall throughout the year. Pandalur, which received the most rainfall of all the test villages, typically received a higher intensity rainfall over a shorter duration, and received most of its rainfall during the southwest monsoon season (Table 5).

Another notably important village was Masinigudi which lies at the heart of the rain shadow and has an annual precipitation of $730 \mathrm{~mm}$. Out of all the villages in the Plains and Southwest Monsoon regions, Masinigudi had the lowest level of precipitation but required the least amount of storage to reach a $90 \%$ reliability level. With a similar trend to Denad, Table 5 showed that Masinigudi had a relatively even distribution of precipitation throughout the year. This result greatly influenced the argument that rainfall distribution had a greater impact on RWH performance than total annual precipitation.

A useful technique used to analyse this observation further was to evaluate the months of the year that had the highest failure rates. Table 6 shows the monthly percent reliability levels, based on an overall reliability level of 90 percent, for the same four villages analysed in Table 5. Even though the villages of Denad and Masinigudi had fewer months with a percent reliability of $100 \%$, there was never a month that fell below 70\%. On the other hand, Pandalur and Mudumalai villages had months where the percent reliabilities fell to $46 \%$ and $56 \%$, respectively. These lower monthly percent reliability levels indicated the need for additional storage (Table 4), which was logical since the RWH system must be able to collect and store enough water during the monsoon seasons to supply the household with water during the dry period. Analyzing the monthly percent reliability was also important for ensuring the RWH systems did not fail for extended periods of time. It is much easier for a household to adjust to enduring scattered days with no water supply than to an extended period without water.

A graphical representation of the relationship between percent reliability and storage capacity is presented in Figure 9. One village from each of the monsoon-influenced regions 
Table 6. Monthly \% Reliability Levels with an Overall Yearly Reliability of $90 \%$

\begin{tabular}{|c|c|c|c|c|c|c|c|c|c|c|c|c|c|}
\hline \multirow{2}{*}{$\begin{array}{c}\text { Test site } \\
\#\end{array}$} & \multirow[t]{2}{*}{ Village } & \multicolumn{12}{|c|}{ Monthly perfect reliability } \\
\hline & & JAN & FEB & MAR & APR & MAY & JUN & JUL & AUG & SEP & OCT & Nov & DEC \\
\hline 1 & Pandalur & 95 & 90 & 46 & 74 & 87 & 98 & 100 & 100 & 100 & 100 & 100 & 100 \\
\hline 2 & Mudumalai & 97 & 82 & 56 & 75 & 84 & 94 & 100 & 100 & 100 & 100 & 100 & 100 \\
\hline 3 & Masinigudi & 100 & 90 & 72 & 80 & 80 & 84 & 92 & 95 & 93 & 100 & 100 & 100 \\
\hline 8 & Denad & 100 & 89 & 68 & 72 & 84 & 87 & 94 & 95 & 98 & 100 & 100 & 100 \\
\hline
\end{tabular}

and two villages from the plains are illustrated in this figure. A general exponential trend was found for all four villages, where Mudumalai had the highest storage requirement. The greatest change in storage occurred between the $95 \%$ and $100 \%$ interval for all four villages, indicating that the benefit of a highly reliable system may not outweigh the resulting economic costs.

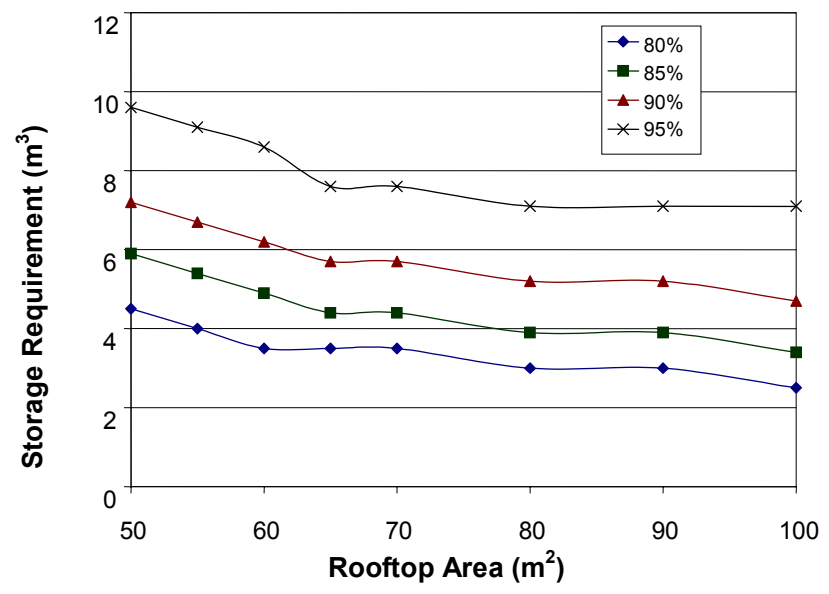

Figure 9. Illustration on the effect of rooftop area on storage requirement for the village of Denad.

An analysis was carried out on the highest performing village of Denad to determine the sensitivity of the RWH model to rooftop area. Since the rooftop area used in the previous analyses was $60 \mathrm{~m}^{2}$, small increments of five square meters were chosen between $50 \mathrm{~m}^{2}$ and $70 \mathrm{~m}^{2}$, and increments of ten above $70 \mathrm{~m}^{2}$. Rooftop areas below 50 were not tested since they did not meet the criterion for the RWH simulation model which does not allow circumstances where the total water supply is less than total water demand. However, the majority of houses in the region have rooftop areas of at least $50 \mathrm{~m}^{2}$ so this was not a probable scenario. Table 7 lists the storage requirements for different combinations of rooftop areas and percent reliabilities.

Results from the analysis agreed with the generally accepted and easily conceptualized rule that when the rooftop area increased, the storage requirements decreased since a greater amount of water was entering the storage unit. More importantly, this analysis showed that the rate at which the storage requirements decreased became smaller as the rooftop area increased. Figure 9 illustrates the rate of decrease for percent reliability levels of $80,85,90$, and 95 percent for the village of Denad. Between the rooftop areas of 50 and $65 \mathrm{~m}^{2}$, the storage requirements decreased quickly compared to those between 65 and $100 \mathrm{~m}^{2}$. This indicated that a point was reached in the RWH design where increasing the rooftop area did not significantly improve the performance of the system. One possible explanation for this trend was the ability of smaller rooftops to provide an adequate supply between short dry periods. In other words, there was no difference in the performance of dissimilar sized rooftops if both rooftops collected enough water to meet the water demand during a series of dry days.

\section{Concluding Remarks}

Countries across the world, both affluent and economically deprived, are treading on the brink of water crises that threaten their way of life and in some cases survival. Water has always been viewed as an abundant resource that is inherently sustainable in nature. This prevalent mentality has persisted to hinder the process of taking measures to preserve this vital resource. To make matters worse, the general consumerist attitude common in modern society creates the need for increased industrial production which pollutes the water resources on a colossal scale. It is only in the past two decades that serious thought has transformed into tangible initiatives and widespread awareness across all levels of society. Even though water is used for many purposes, the most important catalyst for change is the knowledge that humans need water to survive.

The developed prototype DSS called NRWS was designed for application in the Nilgiris District of Southern India. The local information, including the hydrologic data, costing information, and design techniques were incorporated into the program algorithms in order to develop a software program that could be used by an individual with little technical knowledge. The RWH simulation component of NRWS was applied to ten villages across the Nilgiris District and the following conclusions were found:

- the Northeast monsoon influenced region had the highest performance (lowest storage requirement) out of the three 
Table 7. Storage Requirements (in $\mathrm{m}^{3}$ ) for RWH Systems in Denad Village

\begin{tabular}{cccccccccc}
\hline Rooftop area $\left(\mathrm{m}^{2}\right)$ & \multicolumn{7}{c}{ Overall perfect reliability } \\
\cline { 2 - 9 } & 50 & 60 & 70 & 80 & 85 & 90 & 95 & 100 \\
\hline 50 & 0.8 & 1.5 & 2.2 & 4.5 & 5.9 & 7.2 & 9.6 & 15.5 \\
55 & 0.8 & 1.5 & 2.2 & 4.0 & 5.4 & 6.7 & 9.1 & 15 \\
60 & 0.8 & 1.5 & 2.2 & 3.5 & 4.9 & 6.2 & 8.6 & 14.5 \\
65 & 0.8 & 1 & 1.7 & 3.5 & 4.4 & 5.7 & 7.6 & 14 \\
70 & 0.8 & 1 & 1.7 & 3.5 & 4.4 & 5.7 & 7.6 & 14 \\
80 & 0.8 & 1 & 1.7 & 3 & 3.9 & 5.2 & 7.1 & 13.5 \\
90 & 0.8 & 1 & 1.7 & 3 & 3.9 & 5.2 & 7.1 & 12.5 \\
100 & 0.8 & 1 & 1.7 & 2.5 & 3.4 & 4.7 & 7.1 & 12 \\
\hline
\end{tabular}

regions;

- evenly distributed precipitation throughout the year was more significant in achieving high performance than high yearly rainfall;

- achieving a percent reliability above 95\% was not economically feasible due to increased storage requirements; and

- percent reliability did not increase linearly with rooftop area and reached a point where there was no benefit to increasing rooftop area.

The most significant finding from the analysis of RWH feasibility throughout the Nilgiris District was on the results from the village of Masinigudi. Of all the villages tested, Masinigudi was the only village located in the rain shadow of the Plains which received the least rainfall on an annual basis. Villages in the Nilgiris plateau typically use check dams on mountain streams to provide water throughout the year. Villages in the western part of the plains, which receive more intense and frequent precipitation events during the southwest monsoon season, typically employ shallow wells for domestic use. However, neither of these sources were available in the region surrounding Masinigudi, making RWH a valuable resource. Since the RWH units in Masinigudi have one of the lowest storage requirements compared to other villages, implementing this source is economically feasible for the village.

On a global scale, many decision support systems have been developed for application in a range of situations. These generalized DSSs are useful if the factors affecting the system are standardized across the world. However, this is typically not the case where a multitude of diverse systems of hydrologic, technical, socio-economic, and cultural differences exist. As such, site-specific DSSs are more appropriate to deal with unique systems.

Acknowledgments. This research has been supported by the Natural Sciences and Engineering Research Council of Canada. Partner organizations in India, including HADP, RDO Trust, and Myrada, were instrumental in helping to create a locally relevant software program.

\section{References}

Agricultural Engineering Department, Government of Tamil Nadu (2004). Indo-German Bilateral Project "Watershed Management", Project Report of Nallur Representative Watershed (4C1C7b4), Chennai.

Deverill, P., Bibby, S., Wedgwood, A. and Smout, I. (2002). Designing water supply and sanitation projects to meet demand in rural and peri-urban communities. WEDC Publications, Leicestershire, UK.

De Villiers, M. (1999). Water, Stoddart Publishing Company, Toronto, Canada.

Gould, J. and Nissen-Petersen, E. (1999). Rainwater catchment systems for domestic supply: Design, construction, and implementation. Intermediate Technology Publications, UK.

Hanson, G. and Nilsson, A. (1986). Ground-water dams for rural water supply in developing countries. Ground Water, 24(4), 497-506.

Heggen, J. (1996). Value of daily data for rainwater catchment, in Proc. of the Seventh International Rainwater Catchment Systems Conference, Nairobi, Kenya, pp. 413-418.

House, S. and Reed, B. (1997). Emergency water sources: Guidelines for selection and treatment. WEDC Publications, Leicestershire, UK.

Isham, J. and Kahkonan, S. (2002). Institutional determinants of the impact of community-based water services: Evidence from Sri Lanka and India. Econ. Dev. Cult. Change, 50(3), 667-691.

Lal, B. (2002). Restoration of Degraded Forests for the Sustainability of Safe Drinking Water Sources in Rural Areas, Water Resources and Water Supply Department, Government of Gujarat, Gandhinagar.

Olsen, D. (2005). Decision support system for rural water supply in the Nilgiris District of South India. http://www.eng.mcm-

aster.ca/civil/sustain/downloads.html.

Pacey, A. and Cullis, A. (1986). Rainwater Harvesting: The Collection of Rainfall and Runoff in Rural Areas, Intermediate Technology Publications, UK.

Pasteur, K. (2002). Changing Organizations for Watershed Management in India: From Policy to Practice, Institute of Development Studies, Brighton, UK.

Parry-Jones, S. (1999). Optimising the Selection of Demand Assessment Techniques for Water Supply and Sanitation Projects, WELL Publications, UK.

Radhakrishna, B. (2003). Roof-top rainwater harvesting: Measures initiated by the Government of Tamil Nadu. J. Geol. Soc. India, 62(4), 401-404.

Rees, D. (1999). Rainwater Harvesting, ITDG Publishing, UK. 
Ross, S., Jordan, B., Westerfield, R. and Roberts, G. (2002). Fundamentals of Corporate Finance, 4th Canadian Edition. McGraw-Hill Ryerson Limited, Canada.

Sahu, S. (2002). Rainwater harvesting in the Nilgiris: A different approach, Hill Area Development Program.

USAID, (1982). Water for the World: Selecting a Source of Surface Water, Technical Note No. RWS 1.P.3, Washington, DC, USA.

Viessman, W. and Lewis, G. (1996). Introduction to hydrology 4th Edition, Addison-Wesley Educational Publishers, UK
Vyas, V. (1999). Modeling temporal variability in natural resourcesrainwater harvesting systems as an example, Ajit Foundation Technical Report, AFTR-1-99.

WHO (1993). Guidelines for Drinking-Water Quality 2nd Edition, Vol. 3 Surveillance and control of community supplies, World Health Organization.

Wilk, J. and Andersson, L. (2000). GIS-supported modelling of areal rainfall in a mountainous river basin with monsoon climate in Southern India. Hydrol. Sci. J., 45(2), 185-201. 